\title{
BEYOND THE TRIPLE BOTTOM LINE: PROSPERITY, PEOPLE, PLANET, AND PROPHET IN ISLAMIC BANKING
}

\author{
Luthfi Hamidi
}

Andrew C. Worthington

\begin{abstract}
Purpose - We extend the triple bottom line (TBL) framework (Prosperity, People, and Planet (the so-called 3Ps) with a new dimension, namely, Prophet, to reflect Islamic values (the now 4Ps) for organizations seeking compliance with religious principle.

Design/methodology/approach - We conduct a survey of 504 Islamic bank stakeholders across six provinces in Indonesia and employ regression analysis to test the applicability of the 4Ps. We further examine their application in two large Islamic banks in Indonesia and Malaysia.

Findings - The models created are all highly significant and well reflect the broad stakeholder perspective on bank performance. Of the four elements, we find stakeholders rank Prosperity first, followed by Prophet and then Planet. The case study strengthens the application of the new Prophet dimension as a way for Islamic banks to improve their financial, social, and economic performance, particularly during periods of financial distress.
\end{abstract}

Research limitations - We only use survey data from a single country and this may limit the generalizability of the findings.

Practical implications - Practitioners will find the QBL useful in assessing organisational performance, as will regulators seeking to improve the social and economic outcomes of the Islamic banking sector.

Originality/value - This paper internalises maqasid al-syari'ah (the most basic goal of Islamic law) as a simple but essential approach to organisational performance using empirical evidence from a real-world banking setting.

Keywords - triple bottom line, quadruple bottom line, Islamic bank, maqasid al-syari'ah, sustainability

Paper type - Research paper 


\section{Introduction}

The global adoption of sustainable finance is a strategy to develop a financial sector that better aligns with the idea of incorporating social, environmental, and governance in all types of investment (European Commission, 2015). In so doing, not only stockholders but also stakeholders as a whole can enjoy long-lasting economic benefits. The well-known triple bottom line (TBL) framework applying these principles in now evident in almost all organisational types, including private business and government and nongovernmental organisations.

The TBL concept has been considered as one of standard approaches to assess business performance (Norman and MacDonald, 2004; Colbert and Kurucz, 2007). Despite its popularity, some researchers identify several points under concern. The TBL is considered a mere business jargon without sound methodology to assess social and environmental bottom lines as the way profit has been calculated (Norman and MacDonald, 2004). Some clarified the framework might miss innovation dimension, which is paramount importance for sucsessful business (Pinkse and Kolk, 2010; Longoni and Cagliano, 2018). Other propose to include human rights performance and governance given that it is difficult to consider sustainability without addressing these dimensions (Aras and Crowther, 2013) and integrate the concept of total quality management to enable measuring the level of sustainable development (Garvare and Isaksson, 2001). Another concern is on an unclear shifting from focusing profit or prosperity as primary objective to considering people and planet as important dimensions too (Sridar, 2012; Luke and Olugbenga, 2013).

It is surprising only few Islamic financial institutions employ TBL. From the Islamic viewpoint, performance measurement is inseparable from the objectives of Islamic law. Islamic banks are expected to deliver on objectives based on maqasid al-syari'ah (the basic goals of Islamic law). Consequently, the need for establishing specific performance frameworks for Islamic banks has recently become the subject of intense interest. Instead of using TBL, researchers have attempted two approaches to assess Islamic sociodevelopmental performance: adopting corporate social responsibility (Maali et al., 2006; Hassan and Harahap, 2010; Alamer et al., 2015) and developing indexes based on maqasid al-syari'ah (Asutay and Harningtyas, 2015; Bedoui and Mansour, 2015; Mohammed et al., 2015; Rahman et al., 2017; Widardjono, 2018; Lesmana and Haron, 2019). 
Why do they seem to exclude TBL? One possible explanation is that the existing TBL lacks any religiosity dimension as reflection of faith ( $\operatorname{din})$, which is one of five pillars on a Ghazalian maqasid. The absent of this dimension might hide several Islamic bank's unique characteristic to perform. For instance, according to Accounting and Auditing Organization for Islamic Financial Institutions (AAOIFI), Islamic bank requires to declare unlawful transaction (haram business), statement of source and use of zakat (alms giving), source of fund and the amount given to beneficiary in form of qord al-hasan (benevolence loans) (Maali et al., 2006).

The objective of this paper is three folds. First, we propose to integrate the concept of Ghazalian maqasid within the previous well-known TBL principles as a way for nonSyari'ah scholars to more easily engage with its concepts. The current TBL concept (Prosperity, People, Planet) will be extended with another P for Prophet as representative of Islamic religiosity that functioning for ethical guidance and boosting social performance. Second, we assess these new concepts using a survey of Islamic bank stakeholders in Indonesia and test whether any or all pillars significantly influence their perceptions of Islamic bank performance. Third, we observe Bank Muamalat Indonesia (BMI) and Bank Muamalat Malaysia Berhard (BMMB) to consider how their application of the prophet principle has allowed them to turn around their performance during a period of business distress.

There are two mains contribution of this paper. First, we extend the existing literature on bank performance measurement to the next level by integrating maqasid al-syari'ah into an existing and well-accepted framework. Second, we provide empirical evidence to industry practitioners and regulators that the application of spirituality and religiosity in the new approach can enhance financial performance in a real-world context. The structure of the remainder of the paper is as follows. Section 2 reviews the relevant literature and Section 3 describes the methodology. Section 4 discusses the findings. Section 5 concludes.

\section{Literature review}

\subsection{The triple bottomline (TBL)}

Elkington (1997) redefined sustainable capitalism by combining financial and nonfinancial performance. He simplified his approach across three dimensions: the economic, environmental, and social bottom lines, later famously known as the TBL. While there is 
some argument about what terminologically constitutes the TBL, they generally have a similar meaning (Vanclay, 2010). In this paper, we take the TBL to refer to the 3Ps (Prosperity, People, and Planet). We consider Prosperity here as being more meaningful in that the alternative of Profit may indicate a benefit for the firm, but with no direct impact on workers or their communities (Hammer and Pivo, 2017).

In general, TBL concept introduces that firm's performance is much wider than simply concentrates on economic dimension in producing products and services with the best efficiency to create a profit (Prosperity). In additional, a company requires adding social and environmental dimension. A social measurement (People) generally refers how the company contributes to the well being of its employees and surrounding communities where it works. Environmental performance mostly refers to how the company uses its resources (such as energy, land, and water) and how it manages the waste (Hubbard, 2009). A single focus on prosperity may satisfy the firm to be sustainable in the short run, however in the long run all dimensions (Prosperity, People, and Planet) should be met simultaneously (Dyllick and Hockerts, 2002).

The TBL framework has been chosen as the primary framework as it is widely used as a performance measurement in various levels (businesses, non governmental organizations (NGO), and governments). Some industries have adopted TBL for their performance measurement including banking (Luke and Olugbenga, 2013), construction (Kucukvar and Tatari, 2013), retailer (Wilson, 2015), suppliers (Hollos et al., 2012), and Hotel (Assaf et al., 2012). Many NGO and activists organization consider TBL as "an article of faith" (Norman \& MacDonald, 2003: p.2). In addition, in the global level, The United Nations in September 2015 adopted TBL as guidance for developing 17 Sustainable Development Goals.

The TBL framework soon became an essential tool for assessing organisational performance. The measures of the economic bottom line, for instance, include the growth of sales and profits and the returns on assets and equity growth (Hubbard, 2009). Others like Dyllick and Hockerts (2002) suggested also including financial capital (equity and debt), tangible capital (machinery, land, and stock), and intangible capital (reputation and invention). Subsequently, Elkington (1998) added human capital (skills and knowledge-based assets), accountability, and other indicators (including long-term indicators of sustainability). Clearly, although researchers agree about the definition of TBL, there is considerable variance in how to measure it. Some recommend measuring all of the TBL dimensions in a common unit such as 
money. However, some specific measures such as endangered species may be difficult to be monetise, suggesting the use of indexes (Slaper and Hall, 2011).

Finally, some researchers specifically address the application of TBL as a measurement tool. Dyllick and Hockerts (2002) offered six dimensions practitioners could use to maximise corporate sustainability, including eco-efficiency, socio-efficiency, eco-effectiveness, socioeffectiveness, sufficiency, and ecological equity. Hubbard (2009) suggested measuring sustainable performance using the sustainable balanced scorecard (BSC) rather than a pure TBL approach, as the latter was too complex and demanding for managers. He accomplished this by augmenting the conventional BSC approach with additional nonmarket, environmental and social parameters.

\subsection{The purpose of Islamic law (maqasid al-syari'ah)}

Maqasid al-syari'ah means the basic objective of Islamic law. Al-Ghazali explained maqasid al-syari'ah into five categories: (1) preservation of faith (din), (2) protecting soul (nafs), (3) protecting mind ('aql), (4) protecting offspring ( ((Auda, 2008). Abu Zaharah (1997) simplified maqasid al-syari'ah into three domains: education (tahdhib al-fard), justice ( $a l$-'adl), and public interest (al-maslahah). Chapra (2007) argued that while the five goals of maqasid al-syari'ah are the primary (al-ashliyyah) consideration, there are additional or secondary goals (tabi'ah) derived from the Qur'an (the Holy Scripture of Muslim) and the Sunnah (the saying of the Prophet Muhammad peace be upon him).

Maqasid al-syari'ah has been widely developed and applied in economics and finance, particularly in Muslim countries. Dusuki and Abdullah (2007) constructed an implication of maqasid al-syari'ah and maslahah (the public good) to incorporate social responsibility. However, they did not provide a specific framework for measurement. Filling this gap, Mohammed et al., (2008) developed a measurement of Islamic performance based on three pillars of Zaharahan maqasid. They used the Sekaran method to operationalise the maqasid into quantifiable measures and applied their model to six Islamic banks. Later, Bedoui and Mansour (2015) developed a pentagon-shaped performance approach by employing the five pillars of Ghazalian maqasid and subsequently extended it to An-Najjar's eight pillars of maqasid al-syari'ah. Their method incorporated the ethical stance of Islam in quantitative measurement at the macro level, while Asutay and Harningtyas (2015) designed an Islamic 
banking performance framework using An-Najjar's eight pillars of maqasid al-syari'ah and applied it to 13 Islamic banks from six countries over a 5-year period.

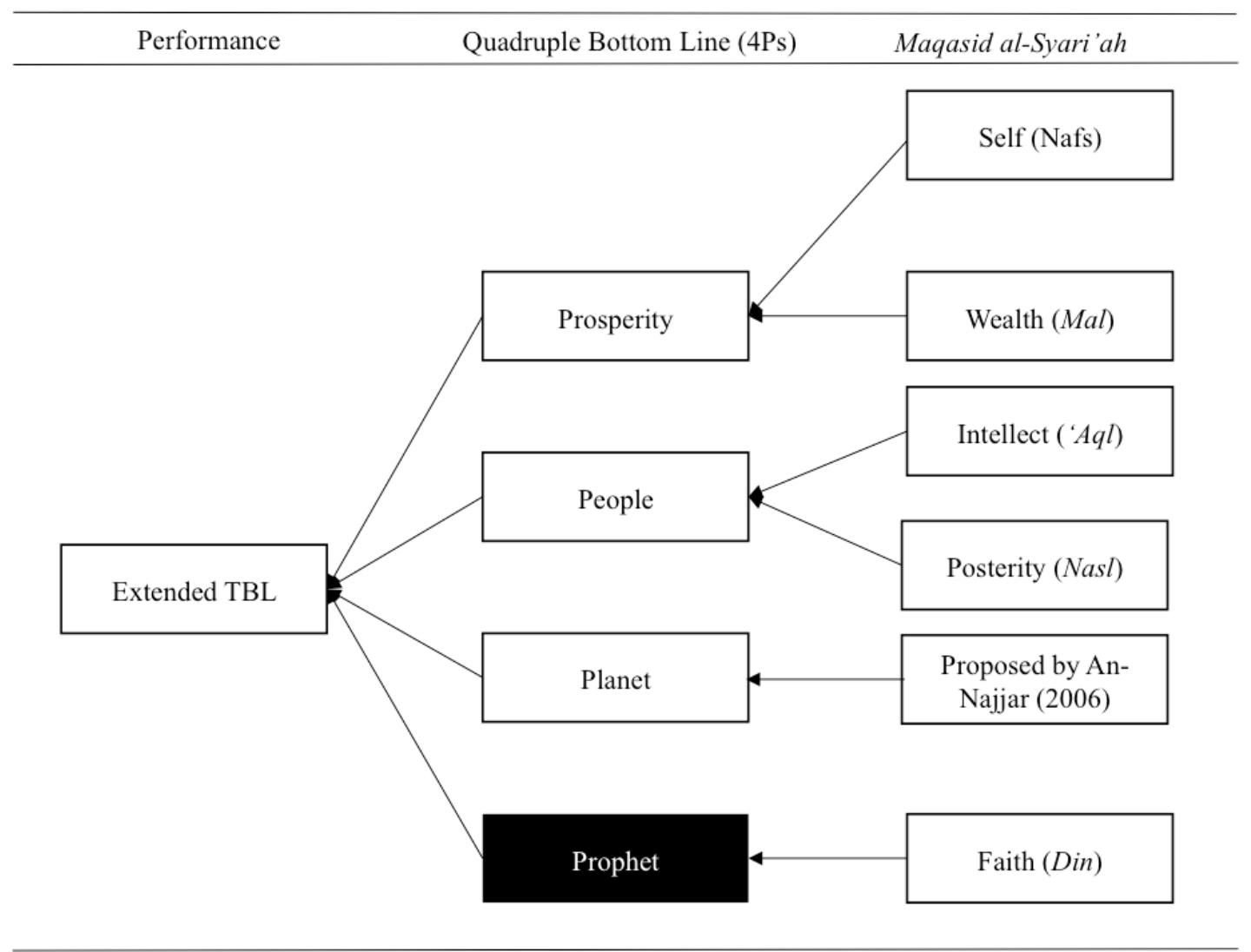

Figure 1. Performance of Islamic banks using QBL principles

In this study we propose augmenting the existing TBL to become the quadruple bottom line (QBL) (Prosperity, People, Planet, and Prophet). We explain QBL using maqasid al-syari'ah principles, as shown in Figure 1. For instance, Prosperity constitutes the safeguarding of self ( $n a f s)$ and wealth (mal); People comprises the safeguarding of intellect ('aql) and posterity (nasl) and Prophet represents the safeguarding of faith (din). We further clarify these four dimensions with corollaries developed by Chapra (2007) along with the dimension of planet proposed by An-Najjar (2006) and his suggestion this is linked with wealth (the dotted line). We adopt the indicators in Allet (2012) to reflect the environment.

\section{Methodology}

\subsection{Data Collection}

We collected the primary data through a survey in Indonesia, including both a drop-off survey and an Internet survey. As there was no opportunity for respondents to seek 
clarification of the questions in the survey in either case, we conducted an online pilot survey from 21 November-29 December 2017 of 137 trial respondents. Based on this pilot test, we developed a new questionnaire, and 420 questionnaires were distributed across five Indonesian provinces (DKI Jakarta, Banten, West Java, Central Java, and DI Yogyakarta), with 274 surveys completed, resulting in a 65\% response rate. With the online survey conducted 1 February-1 March 2018, 245 respondents participated. In total, we collected 519 survey responses, of which 504 (97\%) were usable.

The questionnaire survey is developed based on previous studies (Allet, 2012; Zakaria, 2014; Gait and Worthington, 2015; Mohd Nor et al., 2016). The questionnaire employs close-ended questions using multiple-choice questions and seven-point Likert scale response options. The questionnaire addresses the perceptions of respondents concerning the 4Ps (prosperity, people, planet, and prophet) in Islamic banks.

Data used in our analysis is a mean score generated from Likert scales (calculating a composite score from Likert items). Hence, the data are no longer ordinal, rather continuous. For this reason, it is appropriate to use parametric statistical procedures (Carifio and Perla, 2008; Norman, 2010; Boone and Boone, 2012; Pell, 2005). In addition to the primary data, for the third part of the analysis, we use secondary data from the Bank Muamalat Indonesia (BMI) and Bank Muamalat Malaysia Berhad (BMMB) derived from their annual reports (1998-2006). We further interviewed both the former president directors to seek their experiences in applying the $4 \mathrm{P}$ concept.

\subsection{Sampling}

Table 1 details the profile of the respondents. More males (59.9\% of the sample) participated in this survey than females (40.1\%). Most of the respondents live in West Java (34.3\%), followed by DKI Jakarta (19\%), DI Yogyakarta (17.1\%), Central Java (12.3\%), Outside Java (8.5\%), Banten (4.6\%), and East Java (4.2\%). Most respondents are relatively well educated, with 44 (8.7\%) holding a college diploma, 297 (58.9\%) with a bachelor's degree, 96 (19\%) a master's degree, and $16(3.2 \%)$ a doctorate. Only 47 (9.3\%) of respondents had not completed primary or secondary school. In regard to stakeholders' role, the majority was as depositor (36.8\%) and depositor and practitioner (31.6\%). While the remaining were as depositor and borrower $(17.6 \%)$, depositor and academia (3\%), depositor and regulator $(1.8 \%)$, depositor and syari'ah adviser (0.6\%), depositor and stockholder $(0.4 \%)$, and community $(8.3 \%)$. 
Table 1. Respondent profile

\begin{tabular}{llrr}
\hline Characteristic & Groups & N & \multicolumn{1}{c}{$\%$} \\
\hline Gender & Male & 3 & 59.9 \\
& Female & 2 & 40.1 \\
\hline Province & DKI & 9 & 19.0 \\
& West Java & 1 & 34.2 \\
& Banten & 2 & 4.5 \\
& Central Java & 6 & 12.5 \\
& DIY & 8 & 17.0 \\
& East Java & 2 & 4.3 \\
& Outside Java & 4 & 8.5 \\
\hline Education & Primary/Secondary School & 4 & 9.3 \\
& College Diploma & 4 & 8.7 \\
& Bachelor Degree & 2 & 59.1 \\
& Masters Degree & 9 & 19.0 \\
& Doctoral Degree & 1 & 3.2 \\
& Other & 4 & 0.8 \\
\hline Role & Depositor only & 1 & 36.8 \\
& Depositor \& borrower & 8 & 17.6 \\
& Depositor \& practitioner & 1 & 31.6 \\
& Depositor \& Syari ah adviser & 3 & 0.6 \\
& Depositor \& regulator & 9 & 1.8 \\
& Depositor \& Academia & 1 & 3.0 \\
& Depositor \& Stockholder & 2 & 0.4 \\
& Community/None of above & 4 & 8.3 \\
\hline
\end{tabular}

\subsection{Model and Hypothesis Development}

We propose the following model:

Fin.Perform $=\alpha+\beta_{1}$ Prosperity $+\beta_{2}$ People $+\beta_{3}$ Planet $+\beta_{4}$ Prophet $+\varepsilon$

Dependent variable

Financial performance is the dependent variable (DV). However, instead of conventional financial indicators, we use Likert scales to measure this based on the perception of Islamic banks in the stakeholder survey. The scales are adapted and modified from previous studies (Zakaria, 2014) and based on the balanced scorecard (Kaplan and Norton, 1996) (see appendix).

Independent variables (IVs)

(1) Prosperity. As discussed, prosperity is a broader term than profit or economic growth as these might indicate a benefit for the company and its shareholders but no direct benefit for workers or their communities (Hammer and Pivo, 2017). We explain Prosperity using two Maqasid dimensions, which are self (nafs) and wealth (mal), and Chapra's (2007) five corollaries to explain self, as shown in appendix. We explain wealth (mal) using Chapra's 
(2007) six corollaries (see appendix). Huselid (1995) found that good human resource practices significantly impact on financial performance. Campbell and Mínguez-Vera (2008), also found gender equality improve firm values and generate economic advantages. Our first hypothesis is:

Hypothesis 1. Prosperity positively affects financial performance.

(2) People. This indicates how firms create advantages and other benefits enjoyed through their labours as well as the communities in which these firms conduct their business. We use two pillars of maqasid, intellect ('aql) and posterity (nasl), to reflect and explain this variable. We elaborate on intellect with Chapra (2007)'s four corollaries (see appendix). Hence, our hypothesis is:

Hypothesis 2. People positively affects financial performance.

(3) Planet. While early maqasid al-syari'ah scholars did not include this dimension in their assessments, the Qur'an in a number of verses (30:41-42, 7:56-58, 38:27-28) mentions the urgency of environmental preservation. To address this, we adopt and modify the measure in Allet (2012) (see appendix). Some researchers have investigated the link between environmental preservation and financial performance and mostly suggested that there is a positive relationship between these variables (Stanwick and Stanwick, 1998; Watson et al., 2004). As a result, our hypothesis is:

Hypothesis 3. Planet positively affects financial performance.

(4) Prophet. This dimension reflects the norms and values of the Prophet Muhammad as an ethical guidance for running business. Chapra's (2007) corollaries relating to this dimension are enabling the environment for righteousness, proper motivation, and values (see appendix). In relation to religious norms, it is suggested that an increasing level of religiosity is associated with less risk in misrepresenting financial statements, improved coping skill, increased longevity, and rating of life satisfaction (Dyreng et al., 2012; Brotheridge and Lee, 2007; King and Williamson, 2005).

Religiosity practices in Islamic banks can be seen from how the management facilitates the environment aligns with the moral spirit that can be counted before human beings and God (Hamidi, 2006). Some of religious values, for instance establishing prayer room, reciting 
Qur'an (the holy scripture), distributing zakat and qardh al-hasan, delivering sermon, have been adopted as distinct corporate culture by Bank Muamalat Indonesia (Amin et al., 2004). Understanding the Holy Scripture may encourage businesses' staff to pursue and adhere ethical guidance and spread goodness to entire world. It is not surprising if many elite companies and organizations consider and respect the holy messages to be embraced by their staff, perhaps to inspire and propel their dynamic growth. For instance, Boeing facilitates Christian, Jewish and Muslim prayer group; The American Stock Exchange even has a group based on Torah study; Northrop Grumman sponsors Qur'an classes and other religious programs illustrate the point (McLaughlin, 2005).

In term of distributing zakat and qardh al hasan, Islamic banks will obtain a positive impact on their social responsibility (Gardberg et al., 2019). From an individual view, commitment to do zakat will purify one's income or wealth and hence, it is the way to gain barakah (blessing) from God (Rosman et al., 2019). In general, all the above promotion of religious and spiritual activities as suggested by Asmosh and Duchon (2000) to some extent will improve the commitment and a good workplace for better performance. Based on this, we develop our hypothesis as follows:

Hypothesis 4. Prophet positively affects financial performance.

\section{Results}

\subsection{Assumptions of normality, linearity, homoscedasticity, and reliability}

Table 2 provides descriptive statistics of the dependent and independent variables across the 504 respondents. The highest possible value for all variables is seven and the minimum value possible is one. However, because the data used here is a mean score from the Likert scales (calculating a composite score from Likert items), the lowest value varies across the variables. The standard deviations range between 0.54 and 0.79 reflecting small dispersion from the mean.

Table 2. Descriptive statistics

\begin{tabular}{lcccc}
\hline Dimension & Min. & Max. & Mean & Std. Dev. \\
\hline Prosperity & 3.64 & 7.00 & 5.79 & 0.68 \\
People & 3.38 & 7.00 & 5.71 & 0.79 \\
Planet & 3.33 & 7.00 & 5.89 & 0.77 \\
Prophet & 3.67 & 7.00 & 6.61 & 0.54 \\
Financial performance & 4.00 & 7.00 & 5.97 & 0.69 \\
\hline
\end{tabular}


We found normality issue in our data and used logarithmic transformation to remedy the problem (Tabachnick and Fidell, 2007). After transformation, as shown in Table 3, the distributions now approach normality, because the value of skewness and kurtosis is between -2 and 2 (Gravetter and Wallnau, 2016). Further tests of the unstandardized and standardised residual show the Kolmogorov-Smirnov significant value is .20 (> .05), suggesting that the normality assumption is met. The Shapiro-Wilk significance value of 0.52 further strengthens this finding. Furthermore, Breusch-Pagan and Koenker test statistics confirm this as the significance values of .16 and .25 respectively $(p>.05)$ suggest that heteroscedasticity is not present.

Table 3 Skewness and kurtosis

\begin{tabular}{lcccccccc}
\hline \multirow{2}{*}{ Dimension } & \multicolumn{4}{c}{ Untransformed } & \multicolumn{3}{c}{ Transformed } \\
\cline { 2 - 9 } & \multicolumn{2}{c}{ Skewness } & \multicolumn{2}{c}{ Kurtosis } & \multicolumn{2}{c}{ Skewness } & \multicolumn{2}{c}{ Kurtosis } \\
\cline { 2 - 9 } & Statistic & Std. & Statistic & Std. & Statistic & Std. & Statistic & Std. \\
& & Error & & Error & & Error & & Error \\
\hline Financial performance & -0.771 & 0.109 & 0.523 & 0.217 & -0.130 & 0.109 & -0.298 & 0.217 \\
Prosperity & -0.604 & 0.109 & 0.223 & 0.217 & -0.229 & 0.109 & -0.173 & 0.217 \\
People & -0.414 & 0.109 & -0.341 & 0.217 & -0.353 & 0.109 & -0.448 & 0.217 \\
Planet & -0.614 & 0.109 & -0.149 & 0.217 & -0.151 & 0.109 & -0.646 & 0.217 \\
Prophet & -1.928 & 0.109 & 5.096 & 0.217 & 0.565 & 0.109 & -0.643 & 0.217 \\
\hline
\end{tabular}

We also test for a potential problem with multicollinearity using variance inflation factors (VIFs). A rule of thumb is that if VIF $>10$ then harmful multicollinearity exists. The test indicates that the highest VIF value is 2.06 or less than 10 , so we exclude the presence of multicollinearity.

Lastly, we typically assess the reliability of a construct using Cronbach's Alpha (CA) (Hair et al., 2006). Nunnally (1967) suggested that an alpha between 0.5 and 0.8 is acceptable. The reliability of the five constructs was as follow: FINANCIAL PERFORMANCE (6 items, $\alpha=$ 0.825), PROSPERITY (11 items, $\alpha=0.804$ ), PEOPLE (8 items, $\alpha=0.872$ ), PLANET (6 items, $\alpha=837$ ), PROPHET ( 6 items, $\alpha=0.678$ ). We conclude that the internal consistency within the constructs is within acceptable bounds.

\subsection{Regression results}

Table 4 displays the unstandardized regression coefficient (B) and intercept, the standardised regression coefficient $(\beta)$, squared semi partial correlation $\left(s r^{2}\right), R^{2}$, and adjusted $R^{2}$. Goodness of fit $F(4,499)=100.893, p<.001$, with $R^{2}$ at .447 . The adjusted $R^{2}$ value of .443 indicates that Prosperity, People, Planet, and Prophet predict almost half of the variability in 
financial performance. All the signs of independent variables are positive as predicted. All regression coefficients are significantly different from zero. However, among the estimated coefficients, Prosperity is much more important followed by Prophet, as indicated by the squared semi-partial correlation values of these variables of .059 and .045 , respectively.

Table 4 Coefficient and model summary

\begin{tabular}{lcccccc}
\hline Model & \multicolumn{2}{c}{$\begin{array}{c}\text { Unstandardized } \\
\text { Coefficients }\end{array}$} & $\begin{array}{c}\text { Standardized } \\
\text { Coefficients }\end{array}$ & t-stat. & Sig. & sr $^{2}$ \\
& Coef. & Std. Error & Coef. & & & \\
\hline (Constant) & 0.041 & 0.014 & - & 2.934 & 0.004 & - \\
Prosperity & 0.380 & 0.052 & 0.350 & 7.331 & 0.000 & 0.0595 \\
People & 0.131 & 0.044 & 0.138 & 2.975 & 0.003 & 0.0098 \\
Planet & 0.134 & 0.034 & 0.147 & 3.911 & 0.000 & 0.0169 \\
Prophet & 0.223 & 0.035 & 0.237 & 6.368 & 0.000 & 0.0449 \\
\hline
\end{tabular}

Dependent variable: Financial performance. $\mathrm{R}=0.669$ Adjusted $\mathrm{R}^{2}=0.443$

The fact that the variable of prophet has the second-largest contribution after prosperity differs from previous findings by Asutay and Harningtyas (2015) suggesting that the Islamic banking industry emphasises faith rather than wealth. In reality, other researchers found that rational motives are more prevalent than emotional reasons (religious impact) (Aysan et al., 2018). From the customers point of view, the more religious tend to be more favourable toward Islamic banks. However, their religious involvements are not necessarily significant in regard their attitude to Islamic banking (Souiden and Rani, 2015).

We argue the insertion of the variable prophet in the QBL framework is essential for the guidance of the Islamic business as well as source of motivation of its crews and staffs. From the survey, we can see that most of the respondents are in favour of three items regarding the prophet dimension with the average mean exceeding 6.5 (from a maximum of 7 points) (Table 5). However, the first and second questions are voluntary while only the third is obligatory. Once Islamic banks begin to make the first and second points obligatory, the result may well differ, as we discuss in the cases of BMI and BMMB. The above findings further strengthen previous works that religiosity is associated with less risk in misrepresenting financial statements (Dyreng et al., 2012) and it significantly influences corporate social responsibility (Ramasamy et al., 2010). 
Table 5. Islamic bank stakeholder perceptions of Prophet dimension (\%)

\begin{tabular}{|c|c|c|c|c|c|c|c|c|}
\hline Items & 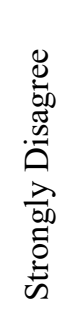 & 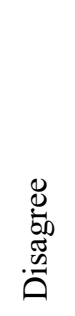 & 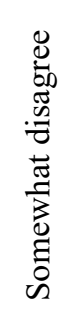 & 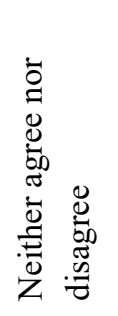 & 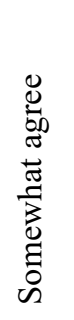 & 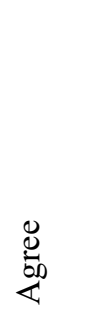 & 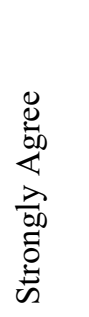 & 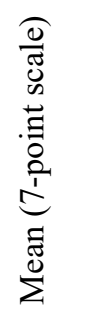 \\
\hline $\begin{array}{l}\text { Islamic banks provide a proper place for the } \\
\text { employees and clients to worship (praying) and } \\
\text { encourage religion activities }\end{array}$ & 0 & 0 & 0 & 1.4 & 1 & 20.2 & 77.4 & 6.74 \\
\hline $\begin{array}{l}\text { The syari'ah bank encourages religious and social } \\
\text { activities (such as Quranic recitation, Religious } \\
\text { studies, Dhuha prayer, alms/charity payment etc) }\end{array}$ & 0 & 0.2 & 0.2 & 2.2 & 3.6 & 29.2 & 64.7 & 6.55 \\
\hline $\begin{array}{l}\text { Islamic banks' products and services are under the } \\
\text { supervision of the Syari'ah Supervisory Board }\end{array}$ & 0.2 & 0 & 0.2 & 2.8 & 1.8 & 31.7 & 63.3 & 6.54 \\
\hline
\end{tabular}

\subsection{Case of BMI and BMMB}

Bank Muamalat Indonesia (BMI) dates from 1991. Because of financial crisis in 1998, BMI's non-performing financing (NPF) exceeded 60\%, and the bank lost nearly IDR105 billion, which cut equity to less than a third of its original paid-up capital, or around IDR39.3 billion (Bank Muamalat Indonesia, 2008). BMI was clearly experiencing distressed circumstances as it moved towards insolvency (Bhattacharyya, 2011). It is interesting to note that the new management of BMI tried hard to survive through many efforts. One of these more nonconventional approaches was to encourage the religiosity of its staff. Table 6 displays some of the religious activities performed as application of prophet dimension (Amin et al., 2004; Bank Muamalat Indonesia, 2008). Except point number 1, previously these actions (point 2 and 3 ) were on a voluntary basis. However, the management committed to perform these more regularly. 
Table 6. Application of Prophet dimension in BMI

\begin{tabular}{|c|c|c|c|c|}
\hline No. & Prophet Dimension & Values/Teaching & Actions & Objectives \\
\hline \multirow{3}{*}{1} & \multirow{3}{*}{$\begin{array}{l}\text { Islamic banks provide a } \\
\text { proper place for the } \\
\text { employees and clients } \\
\text { to worship (praying) } \\
\text { and encourage religion }\end{array}$} & $\begin{array}{l}\text { Believing in the } \\
\text { Hereafter }\end{array}$ & $\begin{array}{l}\text { Signing agreement on ethical } \\
\text { conduct }\end{array}$ & $\begin{array}{l}\text { Preventing moral } \\
\text { hazard and encouraging } \\
\text { integrity }\end{array}$ \\
\hline & & Salat \& dhikr & $\begin{array}{l}\text { Tahajjud on call. Night praying } \\
\text { during the period of training }\end{array}$ & $\begin{array}{l}\text { Self-discipline and } \\
\text { strengthening spiritual } \\
\text { senses and togetherness }\end{array}$ \\
\hline & & Praying room & $\begin{array}{l}\text { Facilitating a proper praying } \\
\text { room that can be accessed by } \\
\text { customers and staffs }\end{array}$ & $\begin{array}{l}\text { Encouraging integrity } \\
\text { of the stuffs and } \\
\text { inviting barakah } \\
\text { (God's blessing) }\end{array}$ \\
\hline \multirow{3}{*}{2} & \multirow{3}{*}{$\begin{array}{l}\text { The Islamic bank } \\
\text { encourages religious } \\
\text { and social activities }\end{array}$} & \multirow{3}{*}{ Zakat } & $\begin{array}{l}\text { Company paid } 2.5 \% \text { annually } \\
\text { from its net profit. Staff paid } \\
2.5 \% \text { deducted from monthly } \\
\text { income }\end{array}$ & $\begin{array}{l}\text { Adherence to syari'ah } \\
\text { rule }\end{array}$ \\
\hline & & & $\begin{array}{l}\text { Aiding zakat calculation service } \\
\text { to clients/customers }\end{array}$ & $\begin{array}{l}\text { Encouraging the } \\
\text { clients/customers in } \\
\text { doing kindness }\end{array}$ \\
\hline & & & $\begin{array}{l}\text { Establishing Institution namely } \\
\text { Baitul Mal Muamalat }\end{array}$ & $\begin{array}{l}\text { Channelling the } \\
\text { collected social fund to } \\
\text { maximize its benefits }\end{array}$ \\
\hline \multirow[t]{2}{*}{3} & \multirow{2}{*}{$\begin{array}{l}\text { Islamic banks' products } \\
\text { and services are under } \\
\text { the supervision of the } \\
\text { Syari'ah Supervisory } \\
\text { Board }\end{array}$} & Governance & $\begin{array}{l}\text { Providing guidance and } \\
\text { supervisory in bank's activities } \\
\text { and the development of } \\
\text { products and services in } \\
\text { accordance with syari'ah } \\
\text { principles. }\end{array}$ & \multirow[t]{2}{*}{$\begin{array}{l}\text { Adhering fully to an } \\
\text { Islamic precept }\end{array}$} \\
\hline & & Supervision & $\begin{array}{l}\text { Conducting active and passive } \\
\text { supervision in relation to the } \\
\text { implementation of syari'ah } \\
\text { banking principles. }\end{array}$ & \\
\hline
\end{tabular}

It was quite surprising that the bank's financial performance began to improve. Although still small, the bank recorded gains of IDR1.88 billion in 2000, following by a steady sequence of profits. At the end of December 2007, BMI recorded an operating profit record of IDR211 billion, up $24 \%$ from the previous period. In a similar fashion, the bank drastically reduced its level of non-performing financing (NPF) from 66\% in 1998 to 4.84\% in 2006 (Figure 2). 


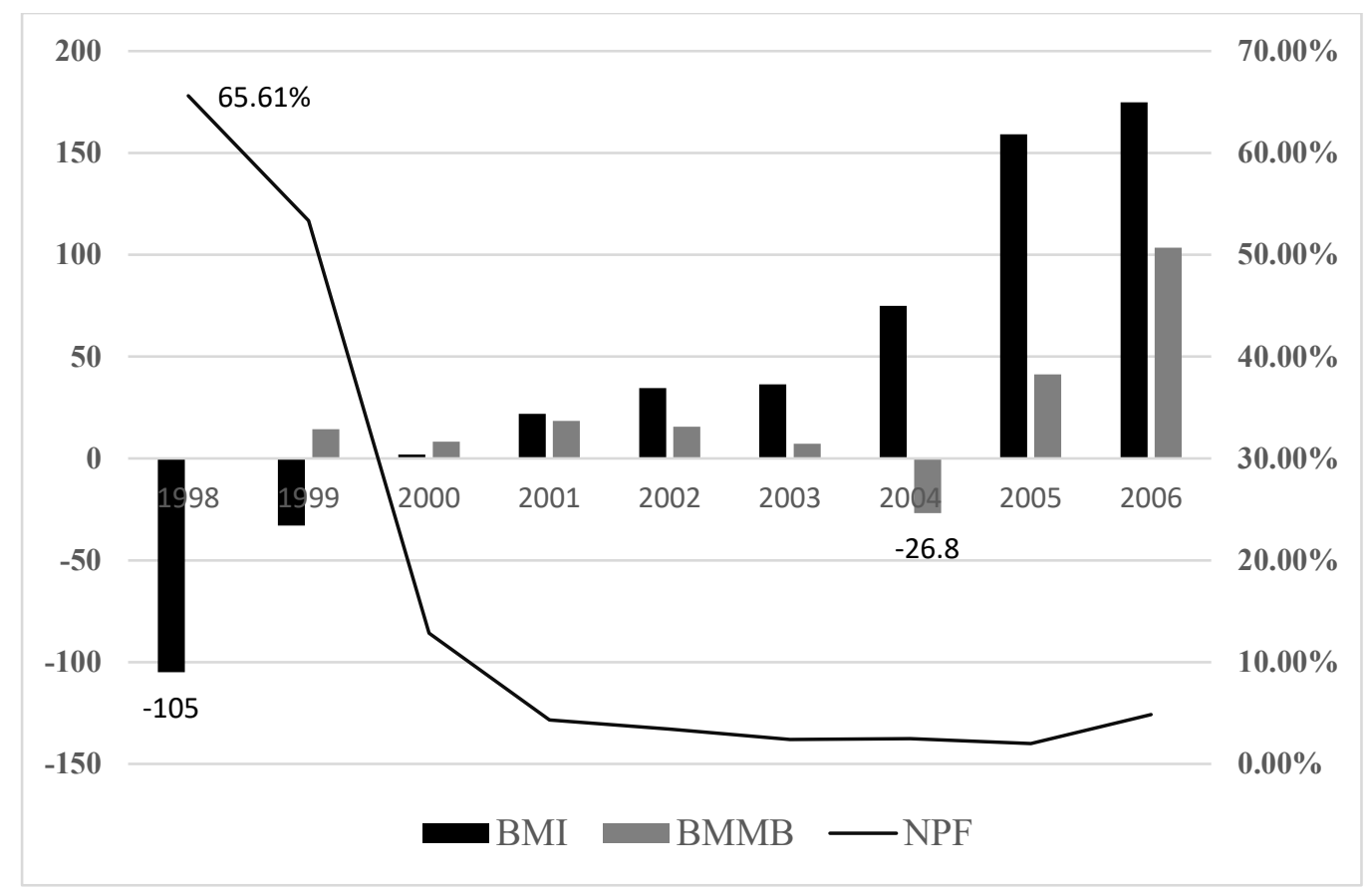

Source: Bank Muamalat Indonesia (2008); Bank Muamalat Malaysia Berhard (2006)

Note: * Operating profit in IDR billion; ** Profit (losses) before tax in Ringgit millions

Figure 2. Financial Performance of $\mathrm{BMI}^{*}$ and $\mathrm{BMMB}^{* *}$

In Malaysia, Bank Muamalat Malaysia Berhad (BMMB) experienced a similar distressed condition. BMMB's financial performance from 1999 to 2001 fluctuated. In 2001, management significantly increased the bank's profit before tax to RM18.4 million. However, profits then continued to decline until 2003 before they drastically fell in 2004, when they recorded a loss of almost RM27 million, its greatest loss ever. In 2005, Dato' Abdul Manap Abd Wahab was appointed as the new CEO. He immediately made a number of key changes, including cutting staff, revamping and streamlining the whole bank, reviewing the bank's products and services, and communicating these changes to staff (personal interview, September 13, 2019). One other policy was to search for an Islamic banking institution to serve as a model for further changes, with BMI chosen. 
Figure 2. Financial Performance of $\mathrm{BMI}^{*}$ and $\mathrm{BMMB}^{* *}$

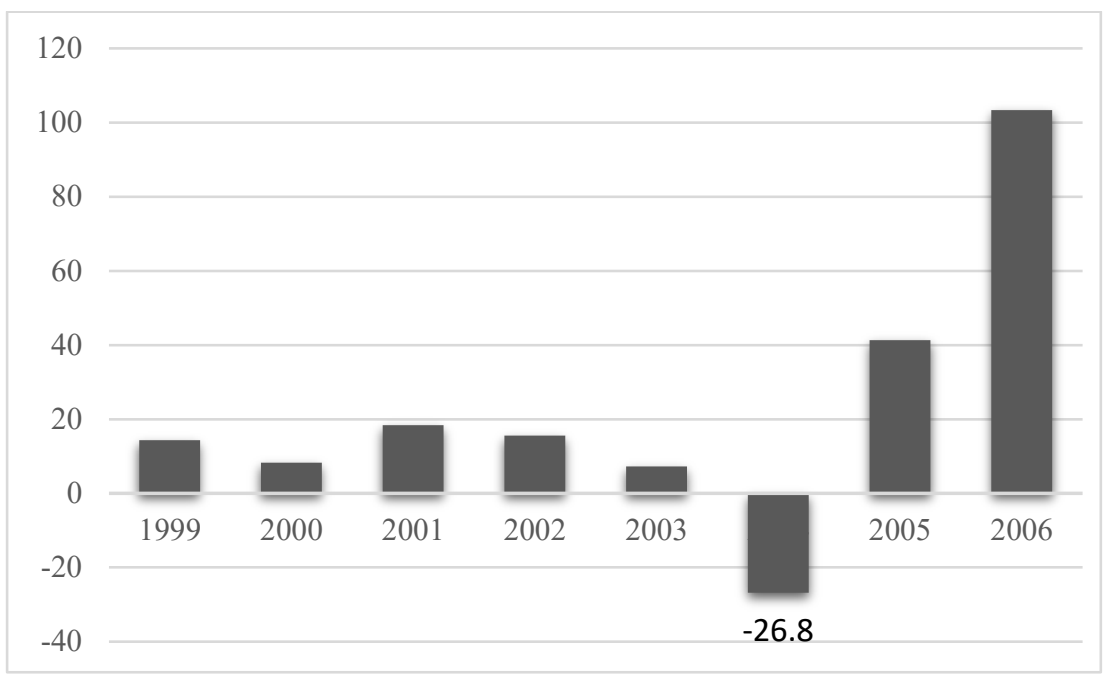

Source: Bank Muamalat Malaysia Berhard (2006)

Figure 3. Profits (losses) before tax, Bank Muamalat Malaysia Berhad (1999-2006)

Following the training of most of its employees in spiritual and managerial skills as in BMI, BMMB's financial performance began to improve. By the end of 2005, management had turned around the bank from its largest losses on record to its greatest profits of RM41.3 million, with profit further improving to RM107 million in the second year (Figure 3). The CEO described the outcomes as follows:

"Prior to the changes we put in place, we were informed that the bank had one of the highest frauds and complaints in the industry. After, putting them through a more purpose-based training providing clarity to their purpose and aligning their personal goals, the staffs attitude and productivity improved considerably, to an extent that the bank did not have any incidents of internal frauds for a significant period" (personal interview, September 13, 2019).

Strengthening this view, former President Director of BMI, A. Riawan Amin (personal interview, September 14, 2019) considered the application of the Prophet dimension as being able to "reduce fraud to less than two digits". This parallels previous research findings by Fathi et al., (2017).

\section{Conclusion}




\subsection{Summary and Implications}

This paper argues that the TBL is inadequate if used to measure the performance of Islamic banks. Instead, we suggest the QBL approach. This extends the existing TBL dimensions covering the economic, social, and environmental dimensions (Prosperity, People, and Planet) with an additional religious dimension referred to as Prophet. Using data collected from a survey with more than 500 participants, our model results in a goodness of fit $F$ (4, $499)=100.893, p<.001$, with an adjusted $R^{2}$ value of .443 . This indicates that Prosperity, People, Planet, and Prophet predict almost half of the variability in performance in Islamic banks. The models created are all highly significant and well reflect the stakeholder perspective on bank performance, and the signs and significance of the independent variables correspond to theory.

Of the four elements, we find stakeholders rank Prosperity first, followed by Prophet and Planet. This somewhat counters the common perception of Islamic banks as emphasising Prosperity to the detriment of People and Planet, and as in our proposed framework, Prophet. A case study application to two large Islamic banks (Bank Muamalat Indonesia and Bank Muamalat Malaysia Berhad) strengthens the application of the new Prophet element as a way for Islamic banks to improve their financial performance and lessen the rampant fraud sometimes found within these organisations.

There are at least three implications of this paper. First, regulators need to adjust the performance measurement of Islamic banks by including requirements for the assessment of Prophet. We argue that the QBL framework proposed here would be a useful construct for regulatory change in countries with large Islamic banking sectors, like Indonesia and Malaysia in Southeast Asia, but also Saudi Arabia, the UAE, Kuwait and Qatar in the Middle East. Second, the experience of BMI and BMMB is at least suggestive that the internalisation of religiosity in bank culture has strengthened their performance.

\subsection{Limitations and Future research}

Our survey data is derived from a single country and this may limit the generalizability of the findings. In addition, the research has been conducted with samples where the majority of respondents are from Java Island, while only $8.5 \%$ of the samples are obtained from out side Java. Further investigation involving multi countries data will be better achievement for developing Islamic finance literature. 
Finally, future research is needed using the QBL framework to create an index so that all dimensions can be captured in a single measure to assess the performance of Islamic banks. We also recommend extra exploration on the changing regulatory initiative that suits the QBL framework, particularly in the environmental and prophetic dimension.

\section{References}

Abu Zaharah, M. (1997), Usul al-fiqh, Dar al-Fikr al-`Arabi, Cairo.

Alamer, A. R. A., Salamon, H. B., Qureshi, M. I., and Rasli, A. M. (2015), “CSR's measuring corporate social responsibility practice in Islamic banking: A review”, International Journal of Economics and Financial Issues, Vol. 5 No. 1S, pp. 198-206.

Allet, M. (2012), "Measuring the environmental performance of microfinance: a new tool", Cost Management, Vol. 26 No. 2, pp. 6-17.

Amin, A. R., Fajrie, A., Hamidi, M. L., and Noer, U. S. (2004), The celestial management: zikr, pikr, mikr, Senayan Abadi Publishing, Jakarta.

Aras, G. and Crowther, D. (2013), "Sustainable Practice: The Real Triple Bottom Line", Crowther, D. and Aras, G. (Ed.) The Governance of Risk (Developments in Corporate Governance and Responsibility, Vol. 5), Emerald Group Publishing Limited, Bingley, pp. 1-18.

Assaf, A. G., Josiassen, A., and Cvelbar, L. K. (2012), "Does triple bottom line reporting improve hotel performance? International Journal of Hospitality Management, Vol. 31 No. 2, pp. 596-600.

Asutay, M., and Harningtyas, A. F. (2015), "Developing Maqasid al-Shari'ah index to evaluate social performance of Islamic banks: A conceptual and empirical attempt”, International Journal of Islamic Economics and Finance Studies, Vol. 1 No. 1, pp. 5-64.

Auda, J. (2008), Maqasid al-Shariah as philosophy of Islamic law: A systems approach, Islamic Research and Training Institute, Jeddah.

Aysan, A. F., Disli, M., Duygun, M., and Ozturk, H. (2018), "Religiosity versus rationality: Depositor behavior in Islamic and conventional banks", Journal of Comparative Economics, Vol. 46 No. 1, pp. 1-19.

Bank Muamalat Indonesia (2008), "STAR WAR: Annual Report 2008, Service Transformation and Revitalisation Wholesale, Alliance, Remote", Available at: http://www.bankmuamalat.co.id/uploads/hubungan investor/1 laporan-tahun2008 20160225145447.pdf (accessed 25 February 2019)

Bank Muamalat Malaysia Berhard (2006), "Annual Report 2006", Available at: https://www.muamalat.com.my/downloads/corporate-overview/annual/2006.pdf (accessed 26 February 2019)

Bedoui, H. E. and Mansour, W. (2015), "Performance and maqasid al-shari'ah's pentagon-shaped ethical measurement", Science and Engineering Ethics, Vol. 21 No. 3, pp. 555-576.

Bhattacharyya, D. (2011), Financial statement analysis, Dorling Kindersley (Licensees of Pearson), New Delhi.

Boone, H. N. and Boone, D. A. (2012), “Analyzing likert data”, Journal of Extension, Vol. 50 No. 2, pp. 1-5.

Brotheridge, C. M. and Lee, R. T. (2007), "Hands to work, heart to God: Religiosity and organizational behavior", Journal of Management, Spirituality \& Religion, Vol. 4 No. 3, pp. 287-309.

Campbell, K. and Mínguez-Vera, A. (2008), "Gender diversity in the boardroom and firm financial performance", Journal of Business Ethics, Vol. 83 No. 3, pp. 435-451.

Carifio, J. and Perla, R. (2008), "Resolving the 50 years debate around using and misusing Likert scales", Medical Education, Vol. 42 No. 12, pp. 1150-1152.

Chapra, M. U. (2007), The Islamic vision of development in the light of maqāsid al-sharī 'ah, Islamic Research and Training Institute, Jeddah.

Colbert, B. A. and Kurucz, E. C. (2007), "Three conceptions of triple bottom line business sustainability and the role for HRM", Human Resource Planning, Vol. 30 No. 1, pp. 21-30.

Dusuki, A. W. and Abdullah, N. I. (2007), "Maqasid al-shari'ah, maslahah and corporate social responsibility", The American Journal of Islamic Social Sciences, Vol. 24 No. 1, pp. 25-45.

Dyllick, T. and Hockerts, K. (2002), "Beyond the business case for corporate sustainability", Business Strategy and the Environment, Vol. 11 No. 2, pp. 130-141.

Dyreng, S. D., Mayew, W. J. and Williams, C. D. (2012), "Religious social norms and corporate financial reporting”, Journal of Business Finance \& Accounting, Vol. 39 No. 7-8, pp. 845-875. 
Elkington, J. (1997), Cannibals with forks: The triple bottom line of twentieth century business, Capstone, Oxford.

Elkington, J. (1998), “Accounting for the triple bottom line”, Measuring Business excellence, Vol. 2 No. 3, pp. $18-22$.

European Commission. (2015), Sustainable finance. Available at: https://ec.europa.eu/info/business-economyeuro/banking-and-finance/sustainable-finance en (accessed 1 February 2019).

Fathi, W. N. I. W. M., Ghani, E. K., Said, J., and Puspitasari, E. (2017), "Potential Employee Fraud Scape in Islamic Banks: The Fraud Triangle Perspective”, Global Journal Al-Thaqafah, Vol. 7 No. 2, pp. $79-93$.

Gait, A., and Worthington, A. C. (2015), "Attitudes of Libyan retail consumers toward Islamic methods of finance", International Journal of Islamic and Middle Eastern Finance and Management, Vol. 8 No. 4, pp. 439-454.

Gardberg, N. A., Zyglidopoulos, S. C., Symeou, P. C., and Schepers, D. H. (2019), "The impact of corporate philanthropy on reputation for corporate social performance”, Business \& Society, Vol. 58 No. 6, pp. 1177-1208.

Garvare, R. and Isaksson, R. (2001), "Sustainable development: extending the scope of business excellence models", Measuring Business Excellence, Vol. 5 No. 3, pp. 11-15.

Gravetter, F. J. and Wallnau, L. B. (2016), Statistics for the behavioral sciences, Cengage Learning, New York.

Hair, J. F., Black, W. C., Babin, B. J., Anderson, R. E., and Tatham, R. L. (2006), Multivariate data analysis (Vol. 6), Upper Saddle River, Pearson Prentice Hall.

Hamidi, M. L. (2006), "The theory and practice of Islamic management style: the experience of bank Muamalat Indonesia", Review of Islamic Economics, Vol. 10 No. 2, pp. 115-131.

Hammer, J. and Pivo, G. (2017), "The triple bottom line and sustainable economic development theory and practice", Economic Development Quarterly, Vol. 31 No. 1, pp. 25-36.

Hassan, A., and Harahap, S.S. (2010), "Exploring corporate social responsibility disclosure: The case of Islamic banks", International Journal of Islamic and Middle Eastern Finance and Management, Vol. 3 No. 3 , pp. 203-227.

Hollos, D., Blome, C., \& Foerstl, K. (2012), "Does sustainable supplier co-operation affect performance? Examining implications for the triple bottom line", International Journal of Production Research, Vol. 50 No. 11, pp. 2968-2986.

Hubbard, G. (2009), "Measuring organizational performance: beyond the triple bottom line", Business Strategy and the Environment, Vol. 18 No 3, pp. 177-191.

Huselid, M. A. (1995), “The impact of human resource management practices on turnover, productivity, and corporate financial performance", Academy of Management Journal, Vol. 38 No. 3, pp. 635-672.

Kaplan, R. S. and Norton, D. P. (1996), "Using the balanced scorecard as a strategic management system", Harvard Business Review, Vol. 74 No. 1, pp. 75-85.

King, J. E. and Williamson, I. O. (2005), "Workplace religious expression, religiosity and job satisfaction: Clarifying a relationship”, Journal of Management, Spirituality \& Religion, Vol. 2 No. 2, pp. 173-198.

Kucukvar, M., and Tatari, O. (2013), "Towards a triple bottom-line sustainability assessment of the US construction industry", The International Journal of Life Cycle Assessment, Vol. 18 No. 5, pp. 958-972.

Kurpis, L. V., Beqiri, M. S. and Helgeson, J. G. (2008), "The effects of commitment to moral self-improvement and religiosity on ethics of business students", Journal of Business Ethics, Vol. 80 No. 3, pp. 447-63.

Lesmana, S. and Haron, M. H. (2019), "Maqasid shariah based performance of Islamic banks, Islamic corporate governance, and contingency theory: a theoretical framework", International Journal of Accounting, Vol. 4 No. 24, pp. 70-86.

Longoni, A. and Cagliano, R. (2018), "Sustainable innovativeness and the triple bottom line: The role of organizational time perspective”, Journal of Business Ethics, Vol. 151 No. 4, pp. 1097-1120.

Luke, O. O., and Olugbenga, A. A. (2013), "Triple bottom line reporting: an assessment of sustainability in banking industry in Nigeria”, Asian Journal of Finance \& Accounting, Vol. 5 No. 2, pp. 127-138.

Maali, B., Casson, P. and Napier, C. (2006), "Social reporting by Islamic banks", Abacus, Vol. 42 No. 2, pp. 266-289.

McLaughlin, C. (2005). Spirituality and ethics in business. European Business Review. DOI:10.1108/EBR.2005.05417AAB.004

Mohammed, M. O., Abdul Razak, D., and Md Taib, F. (2008), “The performance measures of Islamic banking based on the Maqasid framework", In Paper of IIUM International Accounting Conference (INTAC IV) held at Putra Jaya Marroitt, pp. 1-17.

Mohd Nor, S., Rahim, R. A., and Senik, Z. C. (2016), "The potentials of internalising social banking among the Malaysian Islamic banks", Environment, Development and Sustainability, Vol. 18 No. 2, pp. 347-372.

Norman, G. (2010), "Likert scales, levels of measurement and the "laws" of statistics", Advances in Health Sciences Education, Vol. 15 No. 5, pp. 625-632. 
Norman, W. and MacDonald, C. (2004), "Getting to the bottom of "triple bottom line"”, Business Ethics Quarterly, Vol. 14 No.2, pp. 243-262.

Nunnally, J.C. (1967), Psychometric Methods, McGraw-Hill, New York.

Pell, G. (2005), "Use and misuse of Likert scales", Medical Education, Vol. 39 No. 9, pp. 970-971.

Pinkse, J. and Kolk, A. (2010), "Challenges and trade-offs in corporate innovation for climate change", Business Strategy and the Environment, Vol. 19 No. 4, pp. 261-272.

Rahman, F., Tareq, M., Yunanda, R. and Mahdzir, A. (2017), "Maqashid al-shari'ah-based performance measurement for the halal industry", Humanomics, Vol. 33 No. 3, pp. 357-370.

Ramasamy, B., Yeung, M. C., and Au, A. K. (2010), "Consumer support for corporate social responsibility (CSR): The role of religion and values”, Journal of Business Ethics, Vol. 91 No. 1, pp. 61-72.

Rosman, R., Haron, R., and Othman, N. B. M. (2019), "The impact of zakĀt contribution on the financial performance of islamic banks in Malaysia”, Al-Shajarah: Journal of the International Institute of Islamic Thought and Civilization (ISTAC). Special Issue: Islamic banking and Finance, pp. 1-21

Slaper, T. F., and Hall, T. J. (2011), "The triple bottom line: What is it and how does it work", Indiana Business Review, Vol. 86 No. 1, pp. 4-8.

Souiden, N., and Rani, M. (2015), "Consumer attitudes and purchase intentions toward Islamic banks: the influence of religiosity", International Journal of Bank Marketing, Vol. 33 No. 2, pp. 143-161.

Sridhar, K. (2012), "The relationship between the adoption of triple bottom line and enhanced corporate reputation and legitimacy", Corporate Reputation Review, Vol. 15 No. 2, pp. 69-87.

Stanwick, P. A., and Stanwick, S. D. (1998), "The relationship between corporate social performance, and organizational size, financial performance, and environmental performance: An empirical examination", Journal of Business Ethics, Vol. 17 No. 2, pp.195-204.

Tabachnick, B. G., and Fidell, L. S. (2007), Using multivariate statistics, Allyn \& Bacon/Pearson Education, Boston.

Vanclay, F. (2010), "The triple bottom line and impact assessment: how do TBL, EIA, SIA, SEA and EMS relate to each other?" In Tools, Techniques And Approaches For Sustainability: Collected Writings in Environmental Assessment Policy and Management (pp. 101-124), World Scientific.

Watson, K., Klingenberg, B., Polito, T., and Geurts, T. G. (2004), "Impact of environmental management system implementation on financial performance: A comparison of two corporate strategies", Management of Environmental Quality: An International Journal, Vol. 15 No. 6, pp. 622-628.

Widarjono, A. (2018), "Maqasid sharia index, banking risk and performance cases in Indonesian Islamic banks", Asian Economic and Financial Review, Vol. 8 No. 9, pp. 1175-1184.

Wilson, J. P. (2015), "The triple bottom line: Undertaking an economic, social, and environmental retail sustainability strategy”, International Journal of Retail \& Distribution Management, Vol. 43 No. 4/5, pp. $432-447$.

Zakaria, M. (2014), "The influence of human needs in the perspective of maqasid al-syari'ah on zakat distribution effectiveness", Asian Social Science, Vol. 10 No. 3, pp. 165-173. 